\title{
$O$-Arylation of Iodophenols with 2-Fluorobenzaldehyde Under Microwave Conditions
}

\author{
Erika Bálint ${ }^{\mathrm{a}}$, Mónika Kállai ${ }^{\mathrm{b}}$, Orsolya Kovács ${ }^{\mathrm{b}}$, Hedvig Bölcskei ${ }^{\mathrm{c}}$ and György Keglevich ${ }^{\mathrm{b}, *}$
}

${ }^{a}$ MTA-BME Research Group for Organic Chemical Technology, 1521 Budapest, Hungary

${ }^{b}$ Department of Organic Chemistry and Technology, Budapest University of Technology and Economics, 1521 Budapest, Hungary

${ }^{c}$ Gedeon Richter Plc., 1475 Budapest 10, PO Box 27, Hungary

\begin{abstract}
The arylation of 4-iodo-, 2-iodo- and 3-iodophenols with 2-fluorobenzaldehyde may be carried out in the presence of $\mathrm{K}_{2} \mathrm{CO}_{3}$ in DMF as the solvent under microwave conditions. The arylation of 4-iodophenole was promoted by the use of triethylbenzylammonium chloride (TEBAC) as the phase transfer catalyst. In the other model reactions, the use of TEBAC was harmful. By-products formed by isomerization and disproportionation were also detected.
\end{abstract}

Keywords: 2-Flourobenzaldehyde, Iodophenols, Arylation, Microwave, Phase transfer catalysis.

\section{INTRODUCTION}

Phenoxyphenyl moieties are useful building blocks in the field of voltage gated sodium channel (VGSC) blockers. For example's sake the well-known analgesic and antiepilepticum I was synthesized by the $O$-arylation of 4-fluorophenol with 4-F-benzaldehyde in $\mathrm{N}, \mathrm{N}$-dimethylacetamide heating with $\mathrm{K}_{2} \mathrm{CO}_{3}$, the next step was the reaction with semicarbazide hydrochloride and $\mathrm{NaOAc}$ refluxing in $\mathrm{EtOH} / \mathrm{H}_{2} \mathrm{O}[1$, 2]. Ilyin and his coworkers studied $\mathbf{I}$ as a state dependent blocker of mammalian voltage gated sodium channels [3].<smiles>NC(=O)N/N=C/c1ccc(Oc2ccc(F)cc2)cc1</smiles>

III

Compound I became a starting point for further VGSC blockers. Later its ring closed derivatives [4, 5], including

*Address correspondence to this author at the Department of Organic Chemistry and Technology, Budapest University of Technology and Economics, 1521, Budapest, Hungary; Tel: 36-1-4631111/5883;

Fax: 36-1-4633648; E-mail: gkeglevich@mail.bme.hu the non-opioid analgesic "2-[3-(3-chloro-5-fluorophenoxy)phenyl]-pyrimidine-4-carboxamide" (II) [4] and others (e.g. III) [5] were also described. These compounds are NaV1.2 sodium channel blockers. Later further derivatives of VGSC blockers were published, where the phenoxyphenyl moiety was combined with a substituted pyridine unit $\mathbf{I V}$ and $\mathbf{V}$ [6, 7] and other derivatives were also described [8-10]. The main diseases areas were ischemic neuronal damage, neurodegenerative problems, Alzheimer's disease, amyotrophic lateral sclerosis (ALS), Parkinson's disease, various types of pain, manic depression.<smiles>Cc1cc(OCCN2CCCCC2)cc(-c2ccc(Oc3ccc(F)cc3)cc2)n1</smiles>

Compounds with phenoxyphenyl moiety containing a thiazolodione unit (VI) was also introduced [11]. The indications were various types of pain, irritable bowel syndrome (IBS), epilepsy, etc.<smiles>CN1C(=O)S/C(=C\c2ccc(Oc3ccc(F)cc3)cc2)C1=O</smiles> 


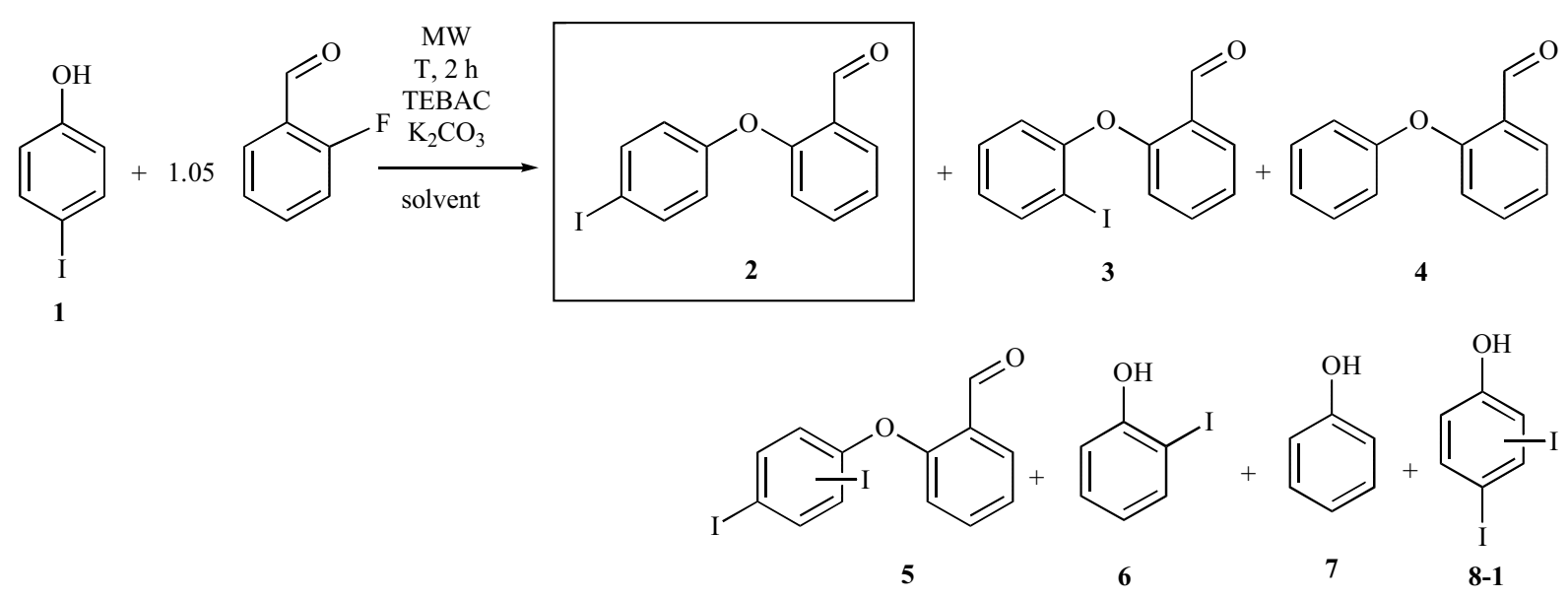

Scheme (1). O-Arylation of 4-Iodophenol (1) Under MW Conditions.

Microwave (MW) irradiation [12-14] and phase transfer catalysis (PTC) [15] represent attractive methods in environmentally friendly chemistry. A few $O$-alkylations of phenol derivatives were described, where there was no need to use a phase transfer catalyst under MW irradiation [1619]. It is noted that MW-assisted heterogeneous phase $C$ alkylations did not require the use of phase transfer catalyst either [20-24]. However, in most cases, the combination of the MW and phase transfer catalytic techniques offered additional advantages [25]. Both $\mathrm{S}-\mathrm{L}$ and $\mathrm{L}-\mathrm{L}$ two phase alkylations of phenols were performed under combined MW-PTC techniques, the former using $\mathrm{K}_{2} \mathrm{CO}_{3} / \mathrm{KOH}$ [26] or $\mathrm{K}_{2} \mathrm{CO}_{3} / \mathrm{NaOH}$ [27] without any solvent, the latter utilizing $\mathrm{NaOH} / \mathrm{H}_{2} \mathrm{O}$ [28]. We found that in the $\mathrm{S}-\mathrm{L}$ phase alkylation of phenols applying $\mathrm{K}_{2} \mathrm{CO}_{3}$ under solvent-free conditions, MW and PTC synergized each other $[29,30]$. This was also true for other $O$-alkylations $[31,32]$. Applying alkyl halides, the situation was similar for the $O$-alkylation of naphtholes. However, the benzylations could be performed best in acetonitrile solutions in the absence of phase transfer catalyst [33].

In this paper, the arylation of 4-, 2- and 3-iodophenols is studied with 2-fluorobenzaldehyde under MW and PTC conditions.

\section{RESULTS AND DISCUSSION}

The first model reaction was the arylation of 4iodophenol (1) with 2-fluorobenzaldehyde in the presence of $\mathrm{K}_{2} \mathrm{CO}_{3}$ with or without triethylbenzylammonium chloride (TEBAC) in the absence or presence of solvent under MW conditions. In general, it was found that beside the expected 4-iodophenyl 2-formylphenyl ether (2), the 2-iodo isomer (3), the dehalogenated ether (4) and variations of the diiodo ethers (5) were also formed (Scheme 1). The unreacted 4iodophenol (1) appeared also as 2-iodophenol (6), phenol (7) and, in a few cases, as diiodophenols (marked generally by structure 8).

The composition of the reaction mixtures depended on the conditions: the use of catalyst and solvent, as well as temperature (Table 1). Carrying out the arylation at $120{ }^{\circ} \mathrm{C}$ for $2 \mathrm{~h}$ without TEBAC and solvent, a quite complex mixture was formed including $42 \%$ of the expected product (2), $4 \%$ of the 2 -iodo isomer (3), $8 \%$ of the dehalogenated product (4) and $8 \%$ of the diiodo components (5). The ethers 2-5 all together represented $62 \%$. The remaining $38 \%$ covered $19 \%$ of unreacted 4 -iodophenol (1), $8 \%$ of 2 iodophenol (6) and $11 \%$ of phenol (7) (Table 1/Entry 1). The use of $5 \%$ or $10 \%$ of TEBAC, on the one hand, increased the proportion of the desired diaryl ether (2) to $46 \%$ and $65 \%$, respectively, on the other hand led to "cleaner" reactions. The different mono- and diiodo isomers $\mathbf{3}$ and $\mathbf{5}$ represented only $6 / 7 \%$, and no dehalogenated product (4) could be detected (Table 1/Entries 2 and 3). However, the conversions remained incomplete. The thermal comparative experiment led to a lower conversion $(41 \%)$, but in respect of the diaryl ethers, the reaction was more selective: beside the $41 \%$ of 2 , only $7 \%$ of the diiodo components (5) were formed (Table 1/Entry 4). Elevation of the reaction temperature to $140{ }^{\circ} \mathrm{C}$ led to a complex mixture containing almost all possible components $(\mathbf{2 - 5}, \mathbf{1}, \mathbf{6}$ and 7) in quantities of 6-36\% (Table 1/Entry 5). Then, we performed the arylations in solvents. In acetonitrile, again a complex mixture was obtained, no matter if $5 \%$ of TEBAC was added in or not. The only positive observation was that the proportion of the diaryl ether products (2-5) amounted to $85 \%$ (Table 1/Entry 6). The use of DMF as the solvent, especially in the presence of increasing amount of TEBAC was very efficient (Table 1/Entries 7-9). The proportion of the expected product 2 in the presence of DMF as the solvent was $67 \%$ (Table 1/Entry 7). Adding $5 \%$ and $10 \%$ of the catalyst, the proportion of iodophenyl 2-formylphenyl ether 2 was $80 \%$ and $92 \%$, respectively (Table 1/Entries 8 and 9). In the latter case, only $8 \%$ of the 2-iodo isomer (3) was present as an additional component meaning that the best option is to carry out the reaction in the presence of $\mathrm{K}_{2} \mathrm{CO}_{3}$ and $10 \%$ of TEBAC in $\mathrm{DMF}$ at $120{ }^{\circ} \mathrm{C}$. The thermal control experiment gave ether (2) in a conversion of $76 \%$. It is noteworthy that only $24 \%$ of unreacted 4-iodophenol (1) was present beside product 2 (Table 1/Entry 10). However, the conversion remained unchanged even after a prolonged heating.

One can see that especially the solvent-free and MWassisted arylations were complicated by isomerization and disproportionation side reactions. The 4-iodophenyl product (2) could be isomerized to the 2-iodo species (3) and the expected product (2) could be disproportionated to 
Table 1. $O$-Arylation of 4-Iodophenol (1) Under MW and Thermal Conditions.

\begin{tabular}{|c|c|c|c|c|c|c|c|c|c|c|c|c|c|c|}
\hline \multirow[b]{2}{*}{ Entry } & \multirow{2}{*}{$\begin{array}{l}\text { Mode of } \\
\text { Heating }\end{array}$} & \multirow[b]{2}{*}{ TEBAC } & \multirow[b]{2}{*}{ Solvent } & \multirow{2}{*}{$\begin{array}{c}\mathrm{T} \\
\left({ }^{\circ} \mathrm{C}\right)\end{array}$} & \multicolumn{10}{|c|}{ Composition of the Reaction Mixtures $(\%)^{a}$} \\
\hline & & & & & 2 & 3 & 4 & 5 & $\begin{array}{c}\sum \\
\text { ethers }\end{array}$ & 1 & 6 & 7 & $8-1$ & $\sum_{\text {phenols }}$ \\
\hline 1 & MW & - & - & 120 & 42 & 4 & 8 & 8 & 62 & 19 & 8 & 11 & 0 & 38 \\
\hline 2 & MW & $5 \%$ & - & 120 & 46 & 3 & 0 & 3 & 52 & 21 & 8 & 12 & 7 & 48 \\
\hline 3 & MW & $10 \%$ & - & 120 & 65 & 2 & 0 & 5 & 72 & 15 & 2 & 5 & 6 & 28 \\
\hline 4 & $\Delta$ & $10 \%$ & - & 120 & 41 & 0 & 0 & 7 & 48 & 30 & 4 & 8 & 10 & 52 \\
\hline 5 & MW & - & - & 140 & 36 & 6 & 12 & 6 & 60 & 8 & 8 & 24 & 0 & 40 \\
\hline 6 & MW & - & $\mathrm{MeCN}$ & 120 & 48 & 14 & 18 & 5 & $85^{\mathrm{b}}$ & 2 & 8 & 5 & 0 & 15 \\
\hline 7 & MW & - & DMF & 120 & 67 & 1 & 9 & 1 & 78 & 14 & 2 & 4 & 2 & 22 \\
\hline 8 & MW & $5 \%$ & DMF & 120 & 80 & 2 & 7 & 2 & 91 & 4 & 2 & 2 & 1 & 9 \\
\hline 9 & MW & $10 \%$ & DMF & 120 & 92 & 8 & 0 & 0 & 100 & 0 & 0 & 0 & 0 & 0 \\
\hline 10 & $\Delta$ & $10 \%$ & DMF & 120 & 76 & 0 & 0 & 0 & $76^{\mathrm{c}}$ & 24 & 0 & 0 & 0 & 24 \\
\hline
\end{tabular}

${ }^{a}$ On the basis of GC and GC-MS measurements.

${ }^{b}$ No change in the presence of $5 \%$ of TEBAC.

${ }^{c}$ No change after a prolonged reaction time of $3 \mathrm{~h}$.

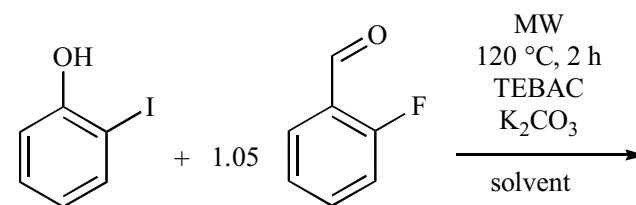

6<smiles>O=Cc1ccccc1Oc1ccccc1I</smiles><smiles>O=Cc1ccccc1Oc1ccccc1I</smiles><smiles>O=Cc1ccccc1Oc1ccc(I)cc1</smiles>

2<smiles>O=CC1=C[C+]=CC=C1Oc1ccccc1</smiles>

4<smiles>Oc1ccc(I)cc1</smiles><smiles>Oc1ccccc1</smiles><smiles>Oc1ccc(I)cc1I</smiles>

8-2

Scheme (2). $O$-Arylation of 2-Iodophenol (6) Under MW Conditions.

dehalogenated ether $\mathbf{4}$ and to diiodo derivatives $\mathbf{5}$. The same kind of side reactions occurred with 4-iodophenol (1) to form by-products (6-8). It is also obvious that the presence of TEBAC, and what is more important, the use of DMF as the solvent promoted a clear-cut, quite selective arylation. Without MW irradiation no complete conversion could be attained. The thermal experiments were more selective, but led to incomplete conversions. Hence, the positive role of MW irradiation is unambiguous.

The next model reaction was the arylation of 2-iodophenol (6) with the same arylating agent, 2-fluorobenzaldehyde. The situation was similar to the previous case: beside the expected product of 2-iodophenyl 2-formylphenyl ether (3), the 4-iodo derivative (2), the dehalogenated and the diiodo products $(4$ and 5) were also formed as a result of isomerization and disproportionation (Scheme 2). The 4-iodophenol (1), phenol (7) and diiodophenols (8) were also formed.
The results are listed in Table $\mathbf{2}$. Regarding the solventfree accomplishments, the composition was more favourable in the absence of TEBAC as compared to the case when it was present. In the absence of catalyst, $50 \%$ of the expected product (3) was formed along with a $29 \%$ portion of the other diaryl ethers (2, 4 and 5) (Table 2/Entry 1). At the same time, in the presence of TEBAC, $32 \%$ of product 3 and $11 \%$ of diaryl ethers 2, 4 and 5 were formed (Table 2/Entry $2)$. It can also be seen that without the catalyst, the ratio of the phenolic components $(\mathbf{6}, \mathbf{1}, 7$, and 8$)$ was $21 \%$, while with TEBAC, the proportion of phenols was $57 \%$. All these experiences suggests that in contrast with the reaction of 4iodophenol (1), in the case of the arylation of 2-iodophenol (6), the presence of TEBAC is harmful, as less of the expected diaryl ether (3) was formed. In acetonitrile without TEBAC, the 2-iodophenyl aryl ether 3 was formed in 55\%, while the other diaryl ethers (2, 4 and 5) only in a small quantity (5\%) (Table 2/Entry 3 ). In DMF, the arylation was 
Table 2. O-Arylation of 2-Iodophenol (6) Under MW Conditions.

\begin{tabular}{|c|c|c|c|c|c|c|c|c|c|c|c|c|}
\hline \multirow[b]{2}{*}{ Entry } & \multirow[b]{2}{*}{ TEBAC } & \multirow[b]{2}{*}{ Solvent } & \multicolumn{10}{|c|}{ Composition of the Reaction Mixtures $(\%)^{a}$} \\
\hline & & & 3 & 2 & 4 & 5 & $\sum_{\text {ethers }}$ & 6 & 1 & 7 & $8-2$ & $\sum_{\text {phenols }}^{\sum}$ \\
\hline 1 & - & - & 50 & 4 & 7 & 18 & 79 & 14 & 0 & 7 & 0 & 21 \\
\hline 2 & $5 \%$ & - & 32 & 3 & 4 & 4 & 43 & 33 & 8 & 8 & 8 & 57 \\
\hline 3 & - & $\mathrm{MeCN}$ & 55 & 1 & 3 & 1 & 60 & 32 & 1 & 6 & 1 & 40 \\
\hline 4 & - & DMF & 85 & - & 2 & 2 & 89 & 11 & 0 & 0 & 0 & 11 \\
\hline 5 & $5 \%$ & DMF & 59 & 14 & 0 & 0 & $73^{\mathrm{b}}$ & 23 & 0 & 0 & 0 & 23 \\
\hline 6 & $10 \%$ & DMF & 76 & 0 & 0 & 0 & $76^{\mathrm{b}}$ & 15 & 0 & 0 & 0 & 15 \\
\hline
\end{tabular}

${ }^{\mathrm{a}}$ On the basis of GC and GC-MS measurements.

${ }^{\mathrm{b}}$ The reaction mixture contained $4-9 \%$ of 2 -iodophenyl benzyl ether.<smiles>O=Cc1ccccc1F</smiles>

MW

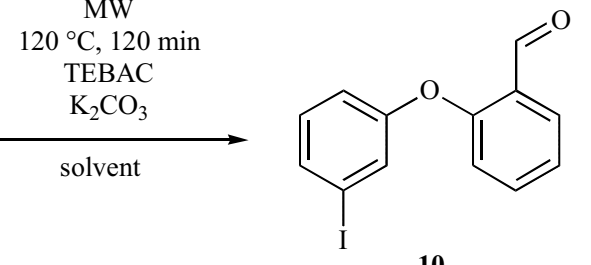

10

Scheme (3). O-Arylation of 3-Iodophenol (9) Under MW Conditions.

Table 3. O-Arylation of 3-Iodophenol (9) Under MW Conditions.

\begin{tabular}{|c|c|c|c|c|c|}
\hline \multirow{2}{*}{ Entry } & \multirow{2}{*}{ TEBAC } & Solvent & \multicolumn{2}{|c|}{ Composition of the Reaction Mixture (\%) $^{\text {a }}$} & \multicolumn{2}{c|}{$\begin{array}{c}\text { Unknown } \\
\text { by-product }\end{array}$} \\
\cline { 3 - 6 } & & - & - & 14 & 80 \\
\hline \hline 1 & $5 \%$ & - & 30 & 66 \\
\hline 3 & - & MeCN & 27 & 73 \\
\hline 4 & - & DMF & 9 & - \\
\hline
\end{tabular}

${ }^{\mathrm{a}} \mathrm{On}$ the basis of GC and GC-MS measurements.

${ }^{\mathrm{b}}$ The reaction mixture contained $2 \%$ of 2 -phenoxy benzaldehyde (4)

more selective and the conversion was higher. $85 \%$ of product 3 was formed at a conversion of $89 \%$ (Table 2/Entry 4). It was not, however, possible to obtain a complete conversion. It was also observed that performing the $O$ arylation in the presence of TEBAC, the proportion of the main product (3) and the conversion were somewhat lower (Table 2/Entries 5 and 6). Moreover, a new by-product 2iodophenyl benzyl ether coming from the reaction of 2iodophenol with TEBAC was also formed. It is again seen that the catalyst does not enhance a complete and clear-cut arylation.

In the above series, the best reaction was when the two reactants met in DMF solution in the absence of TEBAC. It is surprising that while in the arylation of 4-iodophenol (1) the use of TEBAC is clearly advantageous, the arylation of 2-iodophenol (6) becomes more complex and reluctant in the presence of the catalyst. In the present stage of our work, the reason for this experience is unknown.

The last series of reaction involved the arylation of 3iodophenol (9). As compared to the previous models, this reaction way much simpler (Scheme 3). Only a few byproducts were formed and identified.

In the absence of catalyst and solvent, $80 \%$ of the expected product, 3-iodophenyl 2-formylphenyl ether (10) was formed. The conversion was $86 \%$ (Table 3 /Entry 1 ). In the presence of TEBAC, the proportion of $\mathbf{1 0}$ and the conversion were lower (Table $\mathbf{3} /$ Entry 2 ). In acetonitrile solution without catalyst, $73 \%$ of diaryl ether $\mathbf{1 0}$ was formed without any by-product (Table 3/Entry 3 ). The best experiment was, when the arylation was performed in DMF. This occasion, the main product (10) was formed in $89 \%$. Beside this, $9 \%$ of the starting material (9) and 2\% of 2-phenoxy 


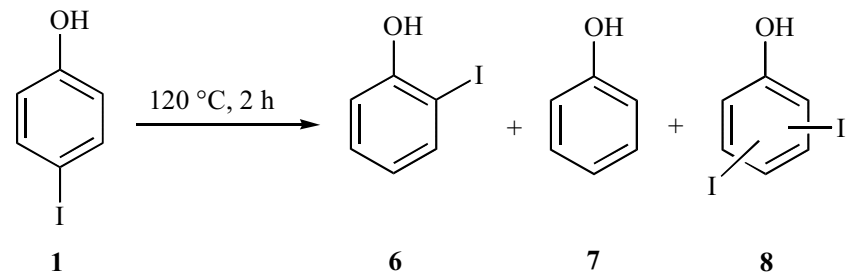

Scheme (4). Disproportionation of 4-Iodophenol (1).

Table 4. Disproportionation of 4-Iodophenol (1) at $120^{\circ} \mathrm{C}$ for $2 \mathrm{~h}$.

\begin{tabular}{|c|c|c|c|c|c|c|c|c|}
\hline Entry & Mode of Heating & $\begin{array}{c}\mathrm{K}_{2} \mathrm{CO}_{3} \\
\text { (1 equiv.) }\end{array}$ & $\begin{array}{c}\text { TEBAC } \\
(5 \%)\end{array}$ & Solvent & 1 & 6 & 7 & 8 \\
\hline 1 & MW & + & - & - & 15 & 29 & 41 & 15 \\
\hline 2 & $\Delta$ & + & - & - & 17 & 27 & 33 & 23 \\
\hline 3 & MW & - & - & $\mathrm{MeCN}$ & 100 & 0 & 0 & 0 \\
\hline 4 & MW & + & - & $\mathrm{MeCN}$ & 51 & 13 & 21 & 15 \\
\hline 5 & MW & + & + & $\mathrm{MeCN}$ & 53 & 11 & 19 & 17 \\
\hline
\end{tabular}

benzaldehyde (4) formed by dehalogenation were present (Table 3/Entry 4).

It can be said that similarly to the case of the arylation of 2-iodophenol (6), the arylation of 3-iodophenol (7) is also disfavored in the presence of TEBAC as the catalyst.

As it was stated above, the reaction mixtures were analyzed by GC and GC-MS. Most of the results listed in Tables 1-3 are the average of 2-3 independent experiments. The main and desired iodophenyl 2-formylphenyl ethers 2, 3 and 10 were obtained by column chromatography from the best experiments that were the runs marked by Table 1/Entry 9, Table 2/Entry 4 and Table 3/Entry 4, respectively. Diaryl ethers 2,3 and $\mathbf{1 0}$ were obtained in yields of $75-85 \%$ in pure forms and were identified by ${ }^{13} \mathrm{C}$ and ${ }^{1} \mathrm{H} \mathrm{NMR}$, as well as mass spectral data. Compound $\mathbf{2}$ was briefly mentioned in the literature [34] without characterization, while species $\mathbf{1 0}$ was characterized only by ${ }^{1} \mathrm{H}$ NMR spectral data [35]. The other components, formed in most of the cases as minor components, were identified on the basis of mass spectrometry.

Finally, the isomerization and disproportionation reaction of 4-iodophenol (1) was studied in "blinde probe" experiments. The possible reaction course is shown in Scheme 4. The results are summarized in Table 4. It can be seen that disproportionation takes place both under MW irradiation and on conventional heating, no matter if a solvent is used or not. In acetonitrile, the conversion of 4-iodophenol was only $51 \%$. No transformation occurred in the absence of $\mathrm{K}_{2} \mathrm{CO}_{3}$. The use of $5 \%$ of TEBAC did not affect the outcome of the reaction. To the best of our knowledge, we are the first to observe these troublesome side reactions. It is also noted that in case of suitably fast concurrent arylations, the side reactions may be depressed.

In conclusion, the arylations of iodophenols with 2fluorobenzaldehyde were optimized under MW conditions. DMF as the solvent was advantageous in all cases, but TEBAC as the phase transfer catalyst enhanced the arylation only in the reaction with 4-iodophenol (1).

\section{EXPERIMENTAL}

\subsection{General}

The chemicals were purchased from Sigma-Aldrich company.

The arylations were carried out in a CEM Discover [300 W] microwave reactor equipped with a pressure controller using 20-30 W irradiation.

GC was carried out on an HP5890 series 2 GC-FID chromatograph, using a $15 \mathrm{~m} \times 0.18 \mathrm{~mm}$ Restek, Rtx-5 column with a film layer of $0.20 \mu \mathrm{m}$. The temperature of the column was initially held at $40{ }^{\circ} \mathrm{C}$ for $1 \mathrm{~min}$, followed by programming at $25{ }^{\circ} \mathrm{C} / \mathrm{min}$. up to $300{ }^{\circ} \mathrm{C}$, and a final period at $300{ }^{\circ} \mathrm{C}$ (isothermal) for $10 \mathrm{~min}$. The temperature of the injector was $290{ }^{\circ} \mathrm{C}$, and of the FID detector $300{ }^{\circ} \mathrm{C}$. The carrier gas was $\mathrm{N}_{2}$.

GC-MS was also carried out on an Agilent 6890 N-GC$5973 \mathrm{~N}-$ MSD chromatograph, using a $30 \mathrm{~m} \times 0.25 \mathrm{~mm}$ Restek, Rtx-5SILMS column with a film layer of $0.25 \mu \mathrm{m}$. The initial temperature of column was $45{ }^{\circ} \mathrm{C}$ for $1 \mathrm{~min}$, followed by programming at $10{ }^{\circ} \mathrm{C} / \mathrm{min}$. up to $310{ }^{\circ} \mathrm{C}$ and a final period at $310{ }^{\circ} \mathrm{C}$ (isothermal) for $17 \mathrm{~min}$. The temperature of the injector was $250{ }^{\circ} \mathrm{C}$. The carrier gas was $\mathrm{He}$ and the operation mode was splitless.

${ }^{13} \mathrm{C}$ and ${ }^{1} \mathrm{H}$ NMR spectra were obtained in $\mathrm{CDCl}_{3}$ solution on a Bruker AV-300 spectrometer operating at 75.5 and $300 \mathrm{MHz}$, respectively. Chemical shifts are downfield relative to $85 \% \mathrm{H}_{3} \mathrm{PO}_{4}$ and TMS.

Mass spectra were obtained using a Q-TOF Premier mass spectrometer in positive electrospray mode.

\subsection{General Procedure for $\boldsymbol{O}$-Arylation of Iodophenols with 2-Fluorobenzaldehyde under MW Conditions}

A mixture of $0.22 \mathrm{~g}(1.0 \mathrm{mmol})$ of 2-, 3- or 4-iodophenol, $0.11 \mathrm{~mL}(1.1 \mathrm{mmol})$ of 2-fluorobenzaldehyde, $0.14 \mathrm{~g}(1.0$ $\mathrm{mmol}$ ) of potassium carbonate and in certain cases $11.4 \mathrm{mg}$ 
$(0.050 \mathrm{mmol})$ of TEBAC in a closed vial was irradiated in a CEM Discover microwave reactor at $120-140{ }^{\circ} \mathrm{C}$ for 2 hours. The reaction mixture was taken up in $25 \mathrm{~mL}$ of ethyl acetate and the suspension was filtered. Evaporation of the volatile components provided the crude product that was passed through a thin (ca. 2-3 cm) layer of silica gel using ethyl acetate as the eluant to give an oil that was analysed by GCMS or GC.

Similar reactions were carried out in $3 \mathrm{~mL}$ of acetonitrile or $N, N$-dimethylformamide as the solvent. The work-up was similar to that described for the solvent-free alkylations above, but in this case, ethyl acetate did not have to be added.

The major components of the above reactions, such as compounds 2, 3 and $\mathbf{8}$ were obtained in a pure form by repeated chromatography as above, but using longer columns.

In a few cases, control experiments were performed in a similar way under conventional heating.

The following compounds were thus prepared:

4-iodophenyl 2-formylphenyl ether (2) [34] Yield: 85\%; ${ }^{13} \mathrm{C}$ NMR $\left(\mathrm{CDCl}_{3}\right): \delta 87.3\left(\mathrm{C}_{4}\right), 118.7\left(\mathrm{C}_{3}\right), 121.3$ $\left(\mathrm{C}_{2}\right), 123.9\left(\mathrm{C}_{5}\right), 127.1\left(\mathrm{C}_{1}\right), 128.7\left(\mathrm{C}_{6}\right), 135.8\left(\mathrm{C}_{4}\right), 139.1$ $\left(\mathrm{C}_{3}\right), 156.6\left(\mathrm{C}_{1}\right), 159.2\left(\mathrm{C}_{2}\right), 189.0(\mathrm{C}=\mathrm{O}) ;{ }^{1} \mathrm{H}$ NMR $\left(\mathrm{CDCl}_{3}\right): \delta 6.83\left(\mathrm{~d}, J=8.6 \mathrm{~Hz}, 2 \mathrm{H}, \mathrm{C}_{2}, \mathrm{H}\right), 6.91(\mathrm{~d}, J=8.3$ $\left.\mathrm{Hz}, 1 \mathrm{H}, \mathrm{C}_{3} \mathrm{H}\right), 7.23\left(\mathrm{t}, J=7.6 \mathrm{~Hz}, 1 \mathrm{H}, \mathrm{C}_{5} \mathrm{H}\right), 7.54(\mathrm{t}, J=7.9$ $\left.\mathrm{Hz}, 1 \mathrm{H}, \mathrm{C}_{4} \mathrm{H}\right), 7.68\left(\mathrm{~d}, J=8.6 \mathrm{~Hz}, 2 \mathrm{H}, \mathrm{C}_{3}, \mathrm{H}\right), 7.95(\mathrm{~d}, J=7.7$ $\left.\mathrm{Hz}, 1 \mathrm{H}, \quad \mathrm{C}_{6} \mathrm{H}\right), 10.46(\mathrm{~s}, 1 \mathrm{H}, \mathrm{C}(\mathrm{O}) \mathrm{H}) ;[\mathrm{M}+\mathrm{Na}]^{+}$found $=$ 346.9547, $\mathrm{C}_{13} \mathrm{H}_{9} \mathrm{O}_{2} \mathrm{NaI}$ requires 346.9545 .

2-iodophenyl 2-formylphenyl ether (3) Yield: $75 \% ;{ }^{13} \mathrm{C}$ $\operatorname{NMR}\left(\mathrm{CDCl}_{3}\right): \delta 89.2\left(\mathrm{C}_{2}\right), 117.3\left(\mathrm{C}_{6}\right), 120.5\left(\mathrm{C}_{3}\right), 123.5$ $\left(\mathrm{C}_{5}\right), 126.3\left(\mathrm{C}_{1}\right), 126.5\left(\mathrm{C}_{4}\right), 128.6\left(\mathrm{C}_{5}\right), 129.9\left(\mathrm{C}_{6}\right), 135.7$ $\left(\mathrm{C}_{4}\right), 140.3\left(\mathrm{C}_{3},\right), 155.4\left(\mathrm{C}_{1},\right), 159.4\left(\mathrm{C}_{2}\right), 189.3(\mathrm{C}=\mathrm{O}) ;{ }^{1} \mathrm{H}$ $\operatorname{NMR}\left(\mathrm{CDCl}_{3}\right): \delta 6.75\left(\mathrm{~d}, J=8.3 \mathrm{~Hz}, 1 \mathrm{H}, \mathrm{C}_{6}, \mathrm{H}\right), 6.96(\mathrm{~d}, J=$ $\left.7.5 \mathrm{~Hz}, 1 \mathrm{H}, \mathrm{C}_{3} \mathrm{H}\right), 6.99\left(\mathrm{t}, J=7.9 \mathrm{~Hz}, 1 \mathrm{H}, \mathrm{C}_{4} \cdot \mathrm{H}\right), 7.20(\mathrm{t}, J=$ $\left.7.4 \mathrm{~Hz}, 1 \mathrm{H}, \mathrm{C}_{5} \mathrm{H}\right), 7.37\left(\mathrm{t}, J=8.1 \mathrm{~Hz}, 1 \mathrm{H}, \mathrm{C}_{5}, \mathrm{H}\right), 7.50(\mathrm{t}, J=$ $\left.8.2 \mathrm{~Hz}, 1 \mathrm{H}, \mathrm{C}_{4} \mathrm{H}\right), 7.91\left(\mathrm{~d}, J=7.8 \mathrm{~Hz}, 1 \mathrm{H}, \mathrm{C}_{3}, \mathrm{H}\right), 7.97(\mathrm{~d}, J=$ $\left.7.7 \mathrm{~Hz}, 1 \mathrm{H}, \mathrm{C}_{6} \mathrm{H}\right), 10.59(\mathrm{~s}, 1 \mathrm{H}, \mathrm{C}(\mathrm{O}) \mathrm{H}) ;[\mathrm{M}+\mathrm{Na}]_{\text {found }}^{+}=$ 346.9551, $\mathrm{C}_{13} \mathrm{H}_{9} \mathrm{O}_{2} \mathrm{NaI}$ requires 346.9545 .

3-iodophenyl 2-formylphenyl ether (10) Yield: 81\%; ${ }^{13} \mathrm{C} \mathrm{NMR}\left(\mathrm{CDCl}_{3}\right): \delta 94.4\left(\mathrm{C}_{3}\right), 118.4\left(\mathrm{C}_{6}\right), 118.9\left(\mathrm{C}_{3}\right)$, $124.0\left(\mathrm{C}_{5}\right), 127.0\left(\mathrm{C}_{1}\right), 128.1\left(\mathrm{C}_{2}\right), 128.7\left(\mathrm{C}_{5}\right), 131.3\left(\mathrm{C}_{6}\right)$, $\left.133.3\left(\mathrm{C}_{4}\right), 135.8\left(\mathrm{C}_{4}\right), 157.0\left(\mathrm{C}_{1}\right)^{\prime}\right), 159.0\left(\mathrm{C}_{2}\right), 188.9(\mathrm{C}=\mathrm{O})$; ${ }^{1} \mathrm{H}$ NMR $\left(\mathrm{CDCl}_{3}\right): \delta 6.92\left(\mathrm{~d}, J=8.3 \mathrm{~Hz}, 1 \mathrm{H}, \mathrm{C}_{6}, \mathrm{H}\right), 7.00-$ $7.14\left(\mathrm{~m}, 2 \mathrm{H}, \mathrm{C}_{3} \mathrm{H}, \mathrm{C}_{5}, \mathrm{H}\right), 7.23\left(\mathrm{t}, J=8.3 \mathrm{~Hz}, 1 \mathrm{H}, \mathrm{C}_{5} \mathrm{H}\right), 7.41$ $\left(\mathrm{s}, 1 \mathrm{H}, \mathrm{C}_{2}, \mathrm{H}\right), 7.52\left(\mathrm{t}, J=8.7 \mathrm{~Hz}, 1 \mathrm{H}, \mathrm{C}_{4} \mathrm{H}\right), 7.56(\mathrm{~d}, J=7.4$ $\left.\mathrm{Hz}, 1 \mathrm{H}, \mathrm{C}_{4} \cdot \mathrm{H}\right), 7.94\left(\mathrm{~d}, J=7.7 \mathrm{~Hz}, 1 \mathrm{H}, \mathrm{C}_{6} \mathrm{H}\right), 10.45(\mathrm{~s}, 1 \mathrm{H}$, $\mathrm{C}(\mathrm{O}) \mathrm{H}) ; \delta[35]\left(\mathrm{CDCl}_{3}\right)$ 6.90-7.96 (m, 8H), $10.48(\mathrm{~s}, 1 \mathrm{H})$; $[\mathrm{M}+\mathrm{Na}]_{\text {found }}^{+}=346.9551, \mathrm{C}_{13} \mathrm{H}_{9} \mathrm{O}_{2} \mathrm{NaI}$ requires 346.9545 .

\section{CONFLICT OF INTEREST}

The authors confirm that this article content has no conflicts of interest.

\section{ACKNOWLEDGEMENTS}

The above project was supported by the Hungarian Scientific and Research Fund (OTKA No K83118).

\section{REFERENCES}

[1] Dimmock, J.R.; Puthucode, R.N. Preparation of phenoxybenzaldehyde semicarbazones as nervous system agents. WO1996040628, US5741818, Chem. Abstr., 1997, 126, 117797.

[2] Puthucode, R.N.; Pugazhenthi, U.; Quail, J.W.; Stables, J.P.; Dimmock, J.R. Anticonvulsant activity of various aryl, arylidene and aryloxyaryl semicarbazones. Eur. J. Med. Chem., 1998, 33, 595-607.

[3] Ilyin, V.I.; Hodges, D.D.; Whittemore, E.R.; Carter, R.B.; Cai, S.X.; Woodward, R.M. V102862 (Co102862): A potent, broadspectrum state-dependent blocker of mammalian voltage-gated sodium channels. British J. Pharmacol., 2005, 144, 801-812.

[4] Victory, S.F.; Kyle, D.J.;Goehring, R.R. Preparation of arylpyrimidines as sodium channel blockers. WO2003076414, Chem. Abstr., 2003, 139, 261310.

[5] Goehring, R.R.; Marra, J.M.; Stasaitis, L.R.; Perez, J. A synthesis of 2-arylpyrimidine-4-carboxylic acid amide derivatives, useful as modulators of $\mathrm{Na}+$ channel activity. WO2004111011, Chem. Abstr., 2004, 142, 74594 .

[6] Goehring, R.R.; Victory, S.F.; Shao, B.; Sun, Q. Preparation of aryl-substituted pyridinecarboxamides as sodium channel blockers for treatment of neuronal damage and neurodegenerative conditions. WO2003022276, Chem. Abstr., 2003, 138, 238021.

[7] Goehring, R.R.; Shao, B. Preparation of substituted 2-(4phenoxyphenyl)pyridine derivatives and related compounds as sodium channel blockers for the treatment of neuronal damage and neurodegenerative conditions. WO2003022285, Chem. Abstr., 2003, 138, 238022.

[8] Sun, Q.; Zhou, X.; Kyle, D.J. Preparation of aryl-substituted benzimidazoles and their use as sodium channel blockers. WO2004011439, Chem. Abstr., 2004, 140, 146139.

[9] Sun, Q.; Kyle, D.J. Aryl substituted hydantoin compounds, their preparation, and their use as sodium channel blockers. WO2004010950, Chem. Abstr., 2004, 140, 157472.

[10] Sun, Q.; Kyle, D.J. Preparation of aminoalkyl-substituted aryl compounds and their use as sodium channel blockers. WO2004013114, Chem. Abstr., 2004, 140, 163577.

[11] Ayer, M.B.; Meinke, P.T.; Parsons, W.H.; Kuo, H.C.H.; Chakravarty, P.K.; Tyagarajan, S.; Preparation of aryloxyaryl, arylheteroaryl, and biaryl methylenethiazolidinediones as sodium channel blockers for the treatment of pain. WO2004024061, Chem. Abstr., 2004, 140, 287373.

[12] Olofsson, K.; Hallberg, A.; Larhed, M. In: Microwaves in Organic Synthesis; Loupy, A., Ed.; Wiley-VCH: Weinheim, 2002; pp. 379403.

[13] Osborne, R. Microwave assisted chemistry. RSC Drug Discov. Ser., 2012, 11, 63-89.

[14] Patel, D.; Patel, B. Microwave assisted organic synthesis: an overview. J. Pharm. Res., 2011, 4, 2090-2092.

[15] Starks, C. M.; Liotta, C. L.; Halpern, M. Phase Transfer Catalysis: Fundamentals, Applications andIndustrial Perspectives, 1st ed.; Chapman \& Hall: New York, 1994

[16] Campbell, L.J.; Borges, L.F.; Heldrich F.J. Microwave accelerated preparation of aryl 2-(N,N-diethylamino)ethyl ethers. Bioorg. Med. Chem. Lett., 1994, 4, 2627-2630.

[17] Sarju, J.; Danks, T.N.; Wagner, G. Rapid Microwave-assisted Synthesis of Phenyl Ethers under Mildly Basic and Non-aqueous Conditions. Tetrahedron Lett., 2004, 45, 7675-7677.

[18] Mitra, A.K.; De, A.; Karchaudhuri, N. Microwave enhanced synthesis of aromatic methyl ether. Indian J. Chem., 2000, 39B, 387-389.

[19] Peng, Y.; Song, G. ombined microwave and ultrasound assisted Williamson ether synthesis in the absence of phase-transfer catalysts. Green Chem., 2002, 4, 349-351.

[20] Keglevich, G.; Novák, T.; Vida, L.; Greiner, I. Microwave irradiation as an alternative to phase transfer catalysis in the liquidsolid phase, solvent-free C-alkylation of active methylene containing substrates. Green Chem., 2006, 8, 1073-1075.

[21] Keglevich, G.; Majrik, K.; Vida, L.; Greiner, I. Microwave irradiation as a green alternative to phase transfer catalysis: Solidliquid phase alkylation of active methylene containing substrates under solvent-free conditions. Lett. Org. Chem., 2008, 5, 224-228.

[22] Greiner, I.; Grün, A.; Ludányi, K.; Keglevich, G. Solid-liquid twophase alkylation of tetraethyl methylenebisphosphonate under microwave irradiation. Heteroatom Chem., 2011, 22, 11-14. 
[23] Keglevich, G.; Grün, A.; Blastik, Z.; Greiner, I. Solid-liquid phase alkylation of $\mathrm{P}=\mathrm{O}$-functionalized $\mathrm{CH}$ acidic compounds utilizing phase transfer catalysis and microwave irradiation. Heteroatom Chem., 2011, 22, 174-179.

[24] Grün, A.; Blastik, Z.; Drahos, L.; Keglevich, G. Microwaveassisted alkylation of diethyl ethoxycarbonylmethylphosphonate under solventless conditions. Heteroatom Chem., 2012, 23, 241246.

[25] Deshayes, S.; Liagre, M.; Loupy, A.; Luche, J. L.; Petit, A. Microwave activation in phase transfer catalysis. Tetrahedron, 1999, 55, 10851-10870.

[26] Bogdal, D.; Pielichowski, J.; Boroń, A. New Synthetic Method of Aromatic Ethers under Microwave Irradiation in Dry Media. Synth. Commun., 1998, 28, 3029-3039.

[27] Pchelka, B. K.; Loupy, A.; Petit, A. Improvement and simplification of synthesis of 3-aryloxy-1,2-epoxypropanes using solvent-free conditions and microwave irradiations. Relation with medium effects and reaction mechanism. Tetrahedron, 2006, 62 , 10968-10979.

[28] Yadav, G.D.; Bisht, P.M. Fundamental analysis of microwave irradiated liquid-liquid phase transfer catalysis (MILL-PTC): Simultaneous measurement of rate and exchange equilibrium constants in selective O-alkylation of p-tert-butylphenol with benzyl chloride. J. Mol. Catal. A-Chem., 2005, 236, 54-64.
[29] Keglevich, G.; Bálint, E.; Karsai, É.; Grün, A.; Bálint, M.; Greiner, I. Chemoselectivity in the microwave-assisted solvent-free solidliquid phase benzylation of phenols: $\mathrm{O}$ - versus C-alkylation. Tetrahedron Lett., 2008, 49, 5039-5042.

[30] Keglevich, G.; Bálint, E.; Karsai, É.; Varga, J.; Grün, A.; Bálint, M.; Greiner, I. Heterogeneous phase alkylation of phenols making use of phase transfer catalysis and microwave irradiation. Lett. Org. Chem., 2009, 6, 535-539.

[31] Bálint, E.; Jablonkai, E.; Bálint, M.; Keglevich, G. Alkylating esterification of 1-hydroxy-3-phopsholene oxides under solventless MW conditions. Heteroatom Chem., 2010, 21, 211-214.

[32] Keglevich, G.; Bálint, E.; Kiss, N.Z.; Jablonkai, E.; Hegedűs, L.; Grün, A., Greiner, I. Microwave-assisted esterification of phosphinic acids. Curr. Org. Chem., 2011, 15, 1802-1810.

[33] Bálint, E.; Kovács, O.; Drahos, L.; Keglevich, G. Microwave-assisted solid-liquid phase alkylation of naphthols. Lett. Org. Chem., (in press).

[34] Jung, N.; Brase, S. Diaryl ether and diaryl thioether syntheses on solid supports via copper (I)-mediated coupling. J. Comb. Chem., 2009, 11, 47-71.

[35] Zimmermann, K.; Roggo, S.; Kragten, E.; Ftirst, P.; Waldmeier, P. Synthesis of tools for target identification of the anti-apoptotic compound CGP 3466. Bioorg. Med. Chem., 1998, 8, 1195-2000. 